\title{
Integrated nutrient management for high productivity and net returns in lentil (Lens culinaris)
}

\author{
Guriqbal Singh*, Harpreet Kaur Virk and Veena Khanna \\ Department of Plant Breeding \& Genetics, Punjab Agricultural University, Ludhiana-141004 (Punjab), INDIA \\ *Corresponding author. E-mail: singhguriqbal@pau.edu
}

Received: December 2, 2016; Revised received: March 6, 2017; Accepted: August 2, 2017

\begin{abstract}
The experiment was conducted to study the integrated nutrient management for high productivity and net returns in lentil. Results revealed that nodulation was significantly $(P \geq 0.01)$ enhanced in treatments comprising of Rhizobium and phosphate solubilizing bacteria (PSB) along with recommended dose of fertilizer (RDF), farmyard manure (FYM) and vermicompost. Treatments comprising of Rhizobium + PSB along with RDF, 50\% RDF, FYM and vermicompost showed higher nodule dry weight as compared to the treatments without biofertilizers. Pods plant ${ }^{-1}$ was highest in RDF + Rhizobium + PSB. Combination of different organic sources with RDF resulted in significantly $(P \geq 0.001)$ higher grain yield than RDF only. RDF $+5 \mathrm{t} \mathrm{ha}^{-1} \mathrm{FYM}$ resulted in 26.3 and 6.7 per cent higher grain yield over control and RDF alone, respectively. RDF + Rhizobium + PSB recorded the highest net returns (Rs 40321 ha $^{-1}$ ) and $\mathrm{B}: \mathrm{C}$ ratio (3.78). It can be concluded that supplementing the recommended dose of nutrients $(12.5 \mathrm{~kg} \mathrm{~N}+40 \mathrm{~kg}$ $\mathrm{P}_{2} \mathrm{O}_{5}$ ha $^{-1}$ ) with $5 \mathrm{t} \mathrm{ha}^{-1} \mathrm{FYM}$ or $2 \mathrm{t} \mathrm{ha}^{-1}$ vermicompost or Rhizobium + PSB inoculation help in obtaining high grain yields and net returns in lentil.
\end{abstract}

Keywords: Grain yield, Lentil, Net returns, Nodulation, Rhizobium

\section{INTRODUCTION}

Lentil (Lens culinaris Medikus) is a protein-rich winter season pulse crop. The use of excessive fertilizers and pesticides are causing environmental hazards and deteriorating soil health. Judicious use of chemical fertilizers in combination with organic manures is required to improve the soil health as well as to achieve sustainable production. It is, therefore, necessary to develop a sustainable production system with maximum productivity and no/minimum environmental pollution. For sustainable production system, integrated use of chemical fertilizers, organic manures such as farmyard manure (FYM) or vermicompost or through the use of biofertilizers such as Rhizobium and phosphate solubilizing bacteria (PSB) helps to meet the nutrient requirement of the crop and providing high productivity (Ram et al., 2013; Deshmukh et al., 2015; Meena and Ram, 2016). Addition of organic manures increases organic carbon, aggregate stability, moisture retention capacity and infiltration rate of the surface soil while reducing the bulk density and also improves grain yield of lentil (Sarkar et al., 2003). Application of biofertilizers (Bera and Pramanik, 2013; Singh et al., 2016), nitrogen (Niri et al., 2010) and phosphorus (Togay et al., 2008; Rasheed et al., 2010; Singh and Singh, 2016) is known to improve plant growth and grain yield in lentil. In this context, an experiment was planned to study the effect of integrated nutrient management (INM) with organic manures, chemical fertilizers and biofertilizers in lentil.

\section{MATERIALS AND METHODS}

A field experiment was conducted during rabi (winter) 2009-10 at the research farm of Punjab Agricultural University, Ludhiana $\left(30^{\circ} 56^{\prime} \mathrm{N}, 75^{\circ} 52^{\prime} \mathrm{E}\right.$, altitude 247 $\mathrm{m})$, India. The soil of the experimental site was loamy sand $(80.3 \%$ sand, $14.3 \%$ silt and $5.4 \%$ clay), having pH 8.7 , organic carbon $0.29 \%$, available phosphorus (P) $11.5 \mathrm{~kg} \mathrm{ha}^{-1}$ and available potassium (K) $410 \mathrm{~kg} \mathrm{ha}^{-1}$. Soil $\mathrm{pH}$ was determined as per the Beckman's Glass Electrode pH Meter (Jackson 1967), organic carbon as per Walkley and Black's Rapid Titration Method (Jackson, 1967), available nitrogen as per Alkaline Potassium Permanganate Method (Subbiah and Asija, 1956), available phosphorus as per $0.5 \mathrm{M}$ sodium bicarbonate extractable method (Olsen et al., 1954) and available potassium as per $1 \mathrm{~N}$ Ammonium Acetate Extractable Method (Merwin and Peech, 1950). A total of $54.6 \mathrm{~mm}$ rainfall was received during the crop growing season. The weekly maximum temperature varied from 11.9 to $35.4{ }^{\circ} \mathrm{C}$ whereas the weekly minimum temperature varied from 3.8 to $17.5{ }^{\circ} \mathrm{C}$ during the crop season.

Sixteen treatments, as given in Table 1, were arranged in a randomized block design with three replications. In the treatment of recommended dose of fertilizers (RDF) as per the Punjab Agricultural University, Lu- 
dhiana, $12.5 \mathrm{~kg} \mathrm{~N}^{-1}$ and $40 \mathrm{~kg} \mathrm{P}_{2} \mathrm{O}_{5} \mathrm{ha}^{-1}$ was applied through urea $(46 \% \mathrm{~N})$ and single superphosphate $\left(16 \% \mathrm{P}_{2} \mathrm{O}_{5}\right)$, respectively. Seed was inoculated with Rhizobium leguminosarum and Bacillus sp. each @ $500 \mathrm{~g} \mathrm{ha}^{-1}$ seed using minimum amount of water in Rhizobium + PSB treatments. Prior to sowing the inoculated seed was dried in shade for one hour. Chemical fertilizers and organic manures (FYM and vermicompost) were applied as per the treatments just before sowing. The sowing of cultivar LL 699 was done in rows $22.5 \mathrm{~cm}$ apart using a seed rate of $35 \mathrm{~kg}$ ha $^{-1}$. Each plot measured $5.0 \mathrm{~m} \times 1.8 \mathrm{~m}$. The crop was harvested on 7 April, 2010. Weeds were controlled by two hand weedings at 30 and 60 days after sowing (DAS). The number of nodules was recorded at 60 and 90 DAS by uprooting five plants from each plot, the roots were washed and nodules detached and counted. The nodule and plant dry weight was recorded after drying at $65^{\circ} \mathrm{C}$. The chlorophyll and leghaemoglobin content was estimated using standard method of Witham et al. (1971) and Wilson and Reisenauer (1963), respectively.

At maturity, data on plant height, primary branches plant $^{-1}$, secondary branches plant ${ }^{-1}$ and pods plant ${ }^{-1}$ were recorded from randomly selected five plants from each plot, and seeds pod ${ }^{-1}$ from randomly selected 20 pods. Biological yield and grain yield was calculated on a plot basis and converted into $\mathrm{kg} \mathrm{ha}^{-1}$. From the produce of each plot 100 seeds were taken for 100-seed weight data. Harvest index (HI) was also calculated by dividing grain yield by total biomass production and then multiplying by 100 . Gross and net returns as well as $\mathrm{B}: \mathrm{C}$ ratio were also worked out. Gross returns were calculated by multiplying the grain yield with minimum support price of Rs $3100 \mathrm{q}^{-1}$. Cost of cultivation was worked out on the basis of the current prices of inputs used in various treatments. Data were subjected to analysis of variance (ANOVA) in a randomized block design as per the standard procedure using CPCS-1 software (Cheema and Singh, 1991).

\section{RESULTS AND DISCUSSION}

The application of Rhizobium and PSB enhanced the number of nodules as compared to uninoculated control and the organic and inorganic amendments alone (Table 1). The nodulation was significantly $(\mathrm{P} \geq 0.01)$ enhanced in treatments comprising of Rhizobium and PSB along with RDF, FYM and vermicompost at 90 DAS. Similarly a notable increase in the nodule dry weight was recorded in these treatments (58.3-61.6 mg plant $^{-1}$ as compared to $45.3 \mathrm{mg} \mathrm{plant}^{-1}$ in the control treatment). As compared to control, the higher number and dry weight of nodules have been reported with the use of organic and inorganic sources of nutrients (Ram et al., 2013) and biofetilizers (Tagore et al., 2013). Treatments comprising of Rhizobium + PSB along with RDF, 50\% RDF, FYM and vermicompost showed significantly $(\mathrm{P} \geq 0.01)$ higher nodule dry weight (58.3$61.6 \mathrm{mg} \mathrm{plant}^{-1}$ ) as compared to the treatments without biofertilizers (47.6-54.0 mg plant ${ }^{-1}$ ) at 90 DAS. The inoculation with PSB in greengram (Vikram and Hamzehzarghani, 2008) and Rhizobium + PSB in chickpea (Tagore et al., 2013) has also been reported to result in higher nodule number, nodule dry weight, and total dry matter. The chlorophyll content was also enhanced when organic amendments were combined with Rhizobium + PSB. Leghaemoglobin content, which is indicative of efficient nitrogen fixation, was at par in treatments of Rhizobium + PSB alone $\left(2.87 \mathrm{mg} \mathrm{g}^{-1}\right.$ fresh weight of nodules) or in combination with FYM, vermicompost and RDF + FYM + vermicompost (2.35-2.82 $\mathrm{mg} \mathrm{g}^{-1}$ fresh weight of nodules). This may be due to the fact that the organic manures have multifarious features such as being rich in nutrients, vitamins and growth regulators. These may have enhanced symbiotic efficiency (Chauhan et al., 2010). Use of co-inoculation of Rhizobium + Klebsiella with farmyard manure has been reported to enhance symbiotic parameters in dry beans (Uyanoz, 2007). Similarly, use of co-inoculation of Rhizobium + PSB with FYM or vermicompost enhanced nodule number and dry weight of nodules in lentil (Ram et al., 2013). Different treatments involving organic manure, chemical fertilizers and biofertilizers did not influence plant height, primary branches plant ${ }^{-1}$ and secondary branches plant ${ }^{-1}$ significantly (Table 2 ). The number of pods plant ${ }^{-1}$, a major yield attributing character, was highest in RDF + Rhizobium + PSB which was, however, at par with RDF $+5 \mathrm{t} \mathrm{ha}^{-1} \mathrm{FYM}, \mathrm{RDF}+2 \mathrm{t}$ $\mathrm{ha}^{-1}$ vermicompost, RDF and RDF + FYM $5 \mathrm{t} \mathrm{ha}^{-1}+$ vermicompost $2 \mathrm{t} \mathrm{ha}^{-1}+$ Rhizobium + PSB. In lentil, Rhizobium inoculation $+\mathrm{N}+\mathrm{P}_{2} \mathrm{O}_{5}$ (Chowdhary et al., 1998) and Rhizobium inoculation $+\mathrm{P}_{2} \mathrm{O}_{5}$ (Singh et al., 2001 ) is known to improve pods plant ${ }^{-1}$. Integrated use of fertilizers with FYM and biofertilizers, in general, also increased seeds $\operatorname{pod}^{-1}$. It was found to be highest in RDF + FYM $5 \mathrm{t} \mathrm{ha}^{-1}+$ vermicompost $2 \mathrm{t} \mathrm{ha}^{-1}+$ Rhizobium + PSB. The treatments had non-significant effect on 100-seed weight.

The treatment with RDF $+5 \mathrm{t} \mathrm{ha}^{-1}$ FYM gave highest grain yield $\left(1777 \mathrm{~kg} \mathrm{ha}^{-1}\right)$ which was at par with RDF $+2 \mathrm{t} \mathrm{ha}^{-1}$ vermicompost, RDF + Rhizobium + PSB and $\mathrm{RDF}+$ FYM $5 \mathrm{t} \mathrm{ha}^{-1}+$ vermicompost $2 \mathrm{t} \mathrm{ha}^{-1}+$ Rhizobium + PSB. This could be due to synergistic effect of various sources of nutrients as application of nutrients (Singh et al., 2000), FYM (Singh et al., 2003) and Rhizobium inoculations (Singh et al., 2000) is known to have beneficial effects in lentil. Rhizobium inoculation improves nodulation in lentil (Chowdhary et al., 1998) and ultimately nitrogen fixation whereas PSB solubilize the native phosphates (El-Sayed, 1999). Therefore, these biofertilizers might have helped in providing nutrients to the plants and ultimately improving the productivity of lentil. Combination of different organic 


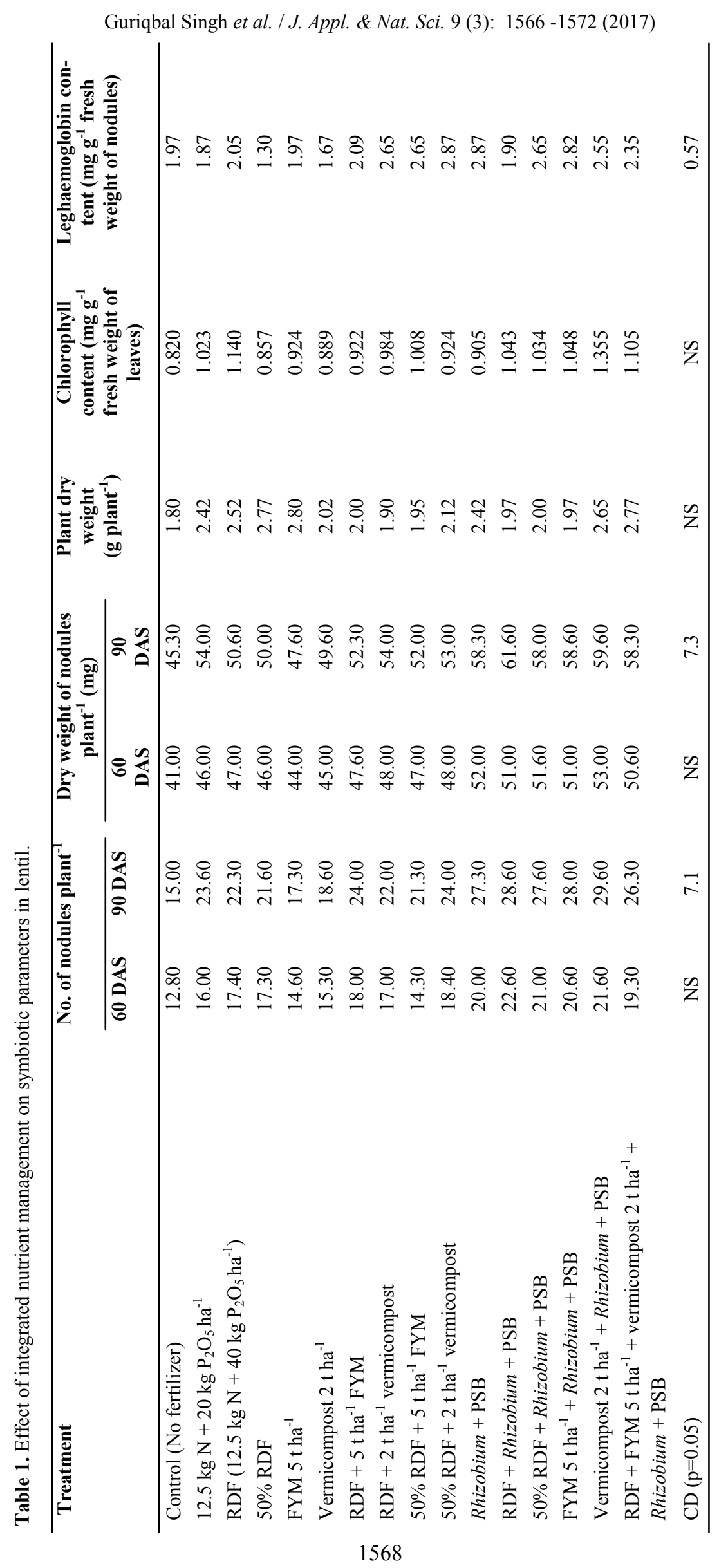


Guriqbal Singh et al. / J. Appl. \& Nat. Sci. 9 (3): 1566 -1572 (2017)

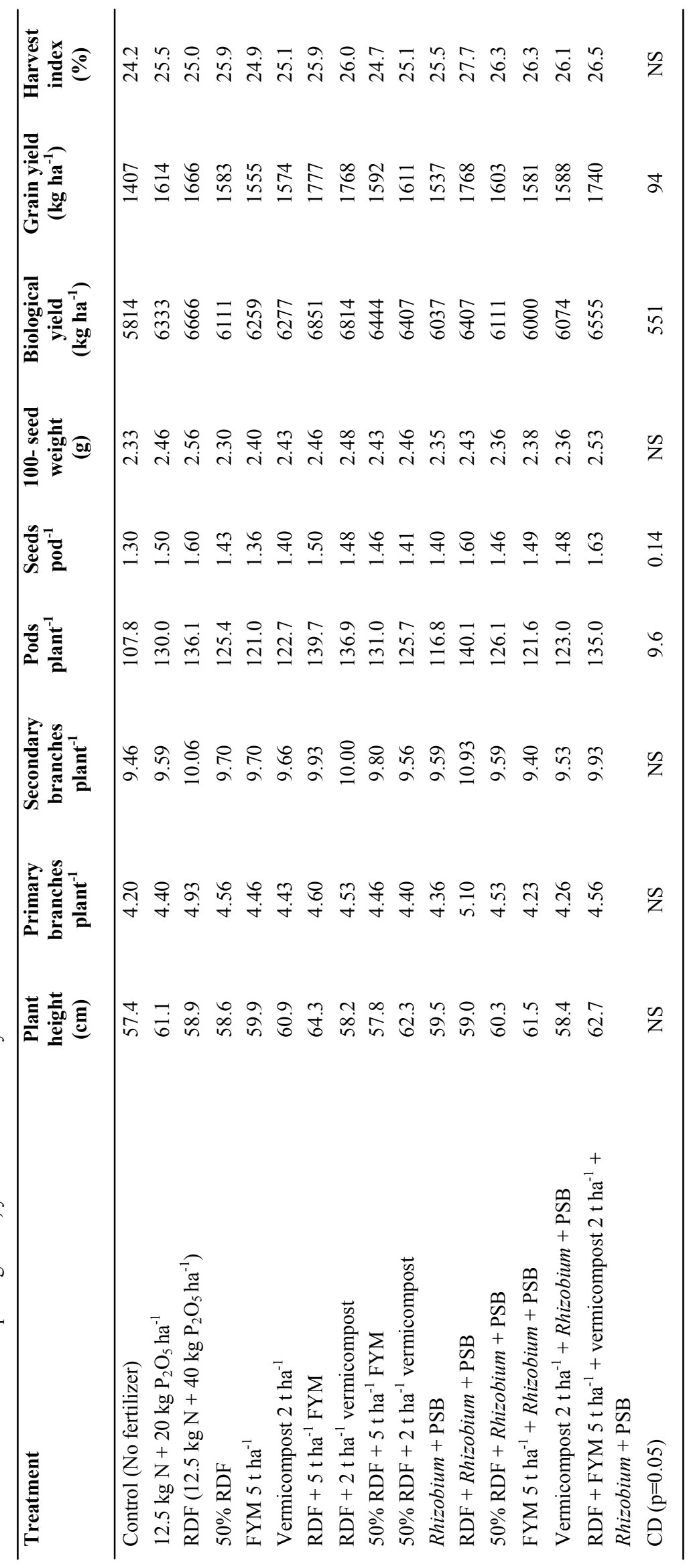


Guriqbal Singh et al. / J. Appl. \& Nat. Sci. 9 (3): 1566 -1572 (2017)

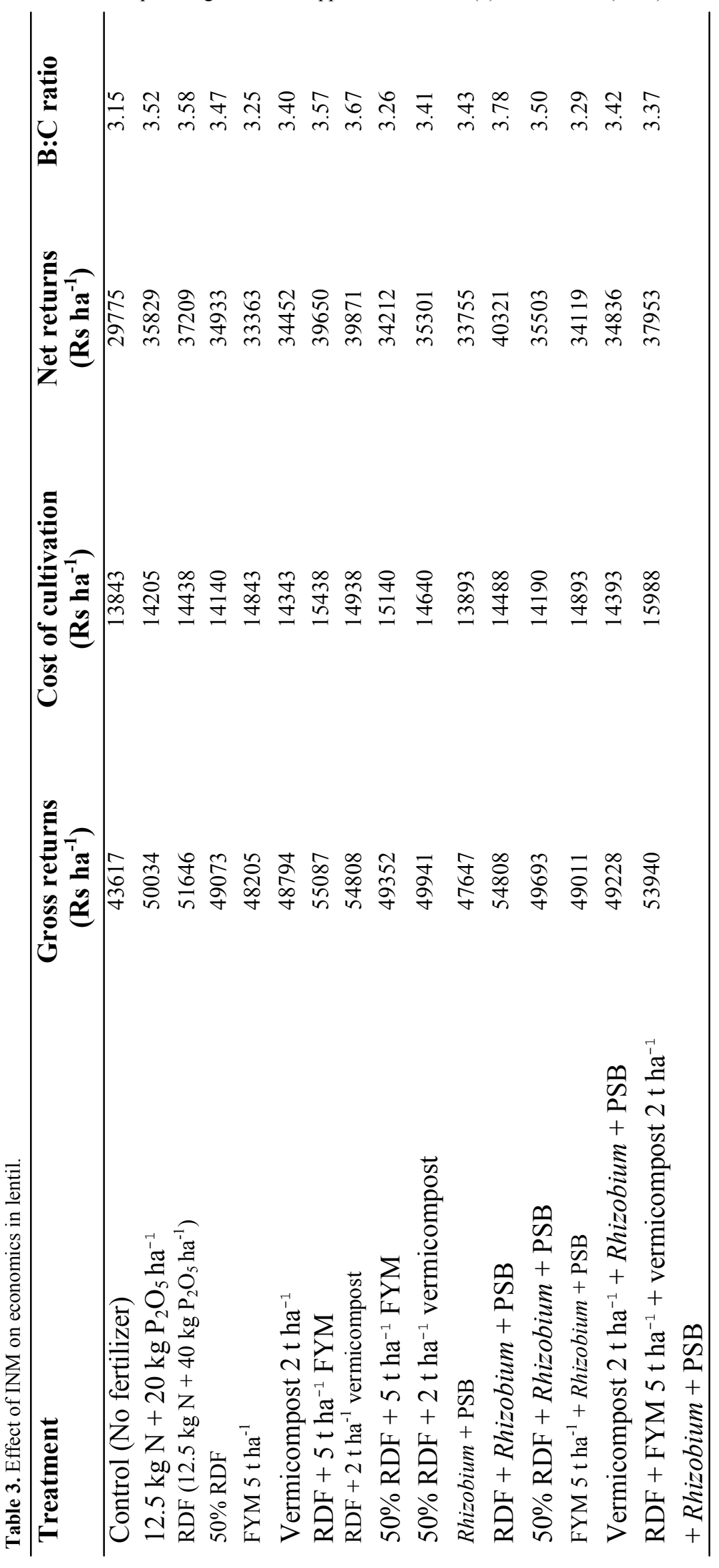


sources with RDF resulted in significantly $(\mathrm{P} \geq 0.001)$ higher grain yield than RDF only. RDF $+5 \mathrm{tha}^{-1} \mathrm{FYM}$ resulted in 26.3 and 6.7 per cent higher grain yield over control and RDF alone, respectively. Integrated use of chemical fertilizers along with organic manures such as FYM and vermicompost as well as biofertilizers improved the grain yield of lentil over their sole application. In the case of chemical nutrients only, use of $12.5 \mathrm{~kg} \mathrm{~N}+40 \mathrm{~kg} \mathrm{P}_{2} \mathrm{O}_{5}$ ha $^{-1}$ provided higher grain yield than with $12.5 \mathrm{~kg} \mathrm{~N}+20 \mathrm{~kg} \mathrm{P}_{2} \mathrm{O}_{5} \mathrm{ha}^{-1}$, though these were statistically at par. Other researchers (Niri et al., 2010) advised the applications of $25 \mathrm{~kg} \mathrm{~N}+40$ $\mathrm{kg} \mathrm{P}_{2} \mathrm{O}_{5}$ ha $^{-1}$ for obtaining high grain yield of lentil in Iran. Optimum use of nutrients is essential for obtaining high grain yields of pulses (Singh et al., 2010a, 2010b, 2011, 2012; Singh, 2013). Harvest index was not significantly influenced by different treatments.

The highest gross returns (Table 3) were obtained with the use of RDF $+5 \mathrm{t} \mathrm{ha}^{-1}$ FYM (Rs $55087 \mathrm{ha}^{-1}$ ), closely followed by $\mathrm{RDF}+2 \mathrm{t} \mathrm{ha}^{-1}$ vermicompost as well as $\mathrm{RDF}+$ Rhizobium + PSB (Rs $54808 \mathrm{ha}^{-1}$ ). RDF + Rhizobium + PSB recorded the highest net returns (Rs $40321 \mathrm{ha}^{-1}$ ) and B:C ratio (3.78).

It can be concluded that supplementing the recommended dose of nutrients $(12.5 \mathrm{~kg} \mathrm{~N}+40 \mathrm{~kg}$ $\mathrm{P}_{2} \mathrm{O}_{5} \mathrm{ha}^{-1}$ ) with $5 \mathrm{tha}^{-1}$ FYM or $2 \mathrm{t} \mathrm{ha}^{-1}$ vermicompost or Rhizobium + PSB inoculation help in obtaining high grain yields and net returns in lentil. High grain yields of lentil were obtained with the use of RDF $+5 \mathrm{t} F Y M$ $\mathrm{ha}^{-1}\left(1777 \mathrm{~kg} \mathrm{ha}^{-1}\right), \quad \mathrm{RDF}+2 \mathrm{t}$ vermicompost $\mathrm{ha}^{-1}$ $\left(1768 \mathrm{~kg} \mathrm{ha}^{-1}\right)$ and RDF + Rhizobium + PSB (1768 kg $\left.\mathrm{ha}^{-1}\right)$, resulting in net returns of Rs 39650, 39871 and $40321 \mathrm{ha}^{-1}$, respectively. The study highlights the role of biofertilizers in lentil, which could play an important role in sustainable agriculture.

\section{ACKNOWLEDGEMENTS}

The authors are thankful to the Indian Council of Agricultural Research, New Delhi for providing financial help and Punjab Agricultural University, Ludhiana for providing facilities for the studies.

\section{REFERENCES}

Bera, A.K. and Pramanik, K. (2013) Effect of biofertilizers and homo-brassinolide on growth, chlorophyll content, yield, nutrient content and uptake of lentil (Lens culinaris Medik.). International Journal of Agriculture, Environment \& Biotechnology, 6: 427-436.

Chauhan, H.S., Joshi, S.C. and Rana, D.K. (2010) Responses of vermicompost on growth and yield of pea (Pisum sativum). Nature Science, 8: 18-21.

Cheema, H.S. and Singh, B. (1991) Software Statistical Package CPCS-1. Department of Statistics, Punjab Agricultural University, Ludhiana, India

Chowdhary, A.K., Newaz, M.A., Samanta, S.C., Huda, S. and Ali, M. (1998) Response of lentil genotypes to cultural environments on nodulation, growth and yield.
Bangladesh Journal of Science and Industrial Research, 33: 258-262.

Deshmukh, C., Singh, R.P., Singh, D. and Sharma, D.P. (2015) Effect of organic, inorganic and biofertilizers on nodulation, yield and economics of lentil (Lens culinaris Medik.) under rainfed conditions. Research in Environment and Life Sciences, 8: 625-628.

El-Sayed, S.A.M. (1999) Influence of Rhizobium and phosphate-solubilizing bacteria on nutrient uptake and yield of lentil in the New Valley (Egypt). Egyptian Journal of Soil Science, 39: 175-186.

Jackson, M.L. (1967) Soil Chemical Analysis. Practice Hall of India Pvt. Ltd. New Delhi.

Meena, B.S. and Ram, B. (2016) Effect of integrated nutrient management on productivity, soil fertility and economics of blackgram (Vigna mungo) varieties under rainfed condition. Legume Research, 39: 268-273.

Merwin, H.D. and Peech, M. (1950) Exchangeability of soil potassium in the sand, silt and clay fractions as influenced by the nature of the complementary exchangeable cations. Soil Science Society of America Proceedings, 15: 125-128.

Niri, H.H., Tobeh, A., Gholipouri, A., Zakaria, R.A., Mostafaei, H. and Jamaati-e-Somarin, S. (2010) Effect of nitrogen and phosphorus on yield and protein content of lentil in dryland condition. American-Eurasian Journal of Agricultural and Environmental Science, 8: 185-188.

Olsen, S.R., Cole, C.V., Watanabe, F.S. and Dean, L.A. (1954) Estimation of available phosphorus by extraction with sodium biocarbonate. USDA Circular, 939: 1-19.

Ram, B., Punia, S.S., Tetarwal, J.P., Meena, D.S. and Tomar, S.S. (2013) Effect of organic and inorganic sources of nutrients on productivity, profitability and soil health in lentil (Lens culinaris) under Vertisols. Indian Journal of Agronomy, 58: 564-569.

Rasheed, M., Jilani, G., Shah, I.A., Najeeb, U. and Iqbal, T. (2010) Improved lentil production by utilizing genetic variability in response to phosphorus fertilization. Acta Agriculturae Scandinavica, Section B: Plant Soil Science, 60: 485-493.

Sarkar, S., Singh, S.R. and Singh, R.P. (2003) The effect of organic and inorganic fertilizers on soil physical condition and the productivity of a rice-lentil cropping sequence in India. Journal of Agricultural Science, 140: $419-425$.

Singh, G. (2013) Effect of phosphorus application and urea spray on growth and yield of summer urdbean [Vigna mungo (L.) Hepper] genotypes. Journal of Plant Science Research, 29: 125-128.

Singh, G., Aggarwal, N. and Khanna, V. (2010a) Integrated nutrient management in lentil with organic manures, chemical fertilizers and biofertilizers. Journal of Food Legumes, 23: 149-151.

Singh, G., Ram, H., Sekhon, H.S., Aggarwal, N. and Khanna, V. (2011) Effect of nutrient management on nodulation, growth and yield of lentil (Lens culinaris Medik.) genotypes. American-Eurasian Journal of Agronomy, 4: 46-49.

Singh, G., Sekhon, H.S. and Kaur, H. (2012) Effect of farmyard manure, vermicompost and chemical nutrients on growth and yield of chickpea (Cicer arietinum L.). International Journal of Agricultural Research, 7: 9399. 
Singh, G., Sekhon, H.S. and Sharma, P. (2001) Effect of Rhizobium, vesicular arbuscular mycorrhiza and phosphorus on the growth and yield of lentil (Lens culinaris) and fieldpea (Pisum sativum). Environment and Ecology, 19: 40-42.

Singh, G., Sekhon, H.S., Ram, H. and Sharma, P. (2010b) Effect of farmyard manure, phosphorus and phosphate solubilizing bacteria on nodulation, growth and yield of kabuli chickpea. Journal of Food Legumes, 23: 226229.

Singh, N. and Singh, G. (2016) Response of lentil (Lens culinaris Medikus) to phosphorus - A review. Agricultural Reviews, 37: 27-34.

Singh, N., Singh, G. and Khanna, V. (2016) Growth of lentil (Lens culinaris Medikus) as influenced by phosphorus, Rhizobium and plant growth promoting rhizobacteria. Indian Journal of Agricultural Research, 50: 567-572.

Singh, O.N., Sharma, M. and Dash, R. (2003) Effect of seed rate, phosphorus and FYM application on growth and yield of bold seeded lentil. Indian Journal of Pulses Research, 16: 116-118.

Singh, Y.P., Chauhan, C.P.S. and Gupta, R.K. (2000) Effect of sulphur, phosphorus and inoculation on growth, yield and sulphur utilization by lentil (Lens culinaris). Indian Journal of Agricultural Sciences, 70: 491-493.

Subbiah, B.K. and Asija, G.L. (1956) A rapid procedure for the extraction of available nitrogen in soil. Current Science, 25: 259-260.
Tagore, G.S., Namdeo, S.L., Sharma, S.K. and Kumar, N. (2013) Effect of Rhizobium and phosphate solubilizing bacterial inoculants on symbiotic traits, nodule leghemoglobin, and yield of chickpea genotypes. International Journal of Agronomy, Vol. 2013, Article ID 581627, 8 pages (http://dx.doi.org/10.1155/2013/ 581627).

Togay, Y., Togay, N. and Dogan, Y. (2008) Research on the effect of phosphorus and molybdenum applications on the yield and yield parameters in lentil (Lens culinaris Medic.). African Journal of Biotechnology, 7: 12561260.

Uyanoz, R. (2007) The effects of different bio-organic, chemical fertilizers and their combination on yield, macro and micro nutrition content of dry bean (Phaseolus vulgaris L.). International Journal of Agricultural Research, 2: 115-125.

Vikram, A. and Hamzehzarghani, H. (2008) Effect of phosphate solubilizing bacteria on nodulation and growth parameters of greengram (Vigna radiata L. Wilczek). Research Journal of Microbiology, 3: 62-72.

Wilson, D.O. and Reisenauer, H.M. (1963) Determination of leghaemoglobin in legume nodules. Annals of Biochemistry, 6: 27-30.

Witham, F.H., Bladydes, D.F. and Delvins, R.M. (1971) Experiment in plant physiology. Van Nostrand Reinhold, New York, pp. 245. 